\title{
Immobilization of whole cells of Lactococcus lactis containing high levels of a hyperthermostable $\beta$-galactosidase enzyme in chitosan beads for efficient galacto-oligosaccharide production
}

\author{
L. Yu and D. J. O'Sullivan ${ }^{1}$ \\ Department of Food Science and Nutrition, Center for Microbial and Plant Genomics, University of Minnesota, 1500 Gortner Ave., St. Paul 55108
}

\begin{abstract}
Galacto-oligosaccharides (GOS) are prebiotic food ingredients that are proposed to stimulate the growth of beneficial gut microorganisms, particularly bifidobacteria. Previously, we developed a method for efficient GOS production using whole cells of Lactococcus lactis containing high levels of a hyper-thermostable $\beta$-galactosidase enzyme from Sulfolobus solfataricus. In this study, a recombinant DNA removal and wholecell enzyme immobilization process was developed to produce GOS from lactose before removal of the immobilized whole-cell enzyme, which could be reused for subsequent applications. Chitosan was found to be a superior immobilization material compared with alginate, as it retained its bead structure during the high temperature $\left(90^{\circ} \mathrm{C}\right)$ used here for GOS production. Prior to immobilization, the recombinant DNA was degraded in the whole cells using UV treatment, resulting in an immobilized whole-cell enzyme that was free of recombinant DNA and with minimum effect on the efficiency of the enzyme. The optimum $\mathrm{pH}$ and temperature for GOS synthesis using the chitosan beads was $\mathrm{pH}$ $=5.5$ and $90^{\circ} \mathrm{C}$. The highest GOS production using the chitosan beads occurred with $40 \%$ initial lactose resulting in $150 \mathrm{~g} / \mathrm{L}$ of GOS (tri-oligosaccharides and tetraoligosaccharides) in addition to di-oligosaccharide GOS products that were not quantified. Notably, the highest lactose conversion rate was found using lower starting lactose concentrations, with more than $60 \%$ conversion into tri-oligosaccharides and tetra-oligosaccharides. The immobilized enzyme retained $\sim 50 \%$ activity after 2 cycles of GOS production. In conclusion, the chitosanimmobilized whole-cell enzyme can be used for efficient GOS production that is free of the whole-cell enzyme as well as detectable recombinant DNA.
\end{abstract}

Received August 30, 2017.

Accepted December 6, 2017.

${ }^{1}$ Corresponding author: dosulliv@umn.edu
Key words: prebiotics, chitosan, Bifidobacterium

\section{INTRODUCTION}

Prebiotics are generally short-chain dietary fibers, which can be fermented by some gut bacteria and have the potential to specifically modulate the gut microflora depending on the type of prebiotic. Previous studies have demonstrated that the dietary intake of galacto-oligosaccharides (GOS) specifically promoted the growth of bifidobacteria and they can therefore be referred to as bifidogenic food ingredients (Depeint et al., 2008; Davis et al., 2010; Veereman-Wauters et al., 2011). It was also shown to reduce infection from Salmonella enterica serotype Typhimurium in a mouse model (Tzortzis et al., 2005; Searle et al., 2009). Consequently, GOS is becoming a very desirable prebiotic food ingredient.

Galacto-oligosaccharides can be produced from lactose using different $\beta$-galactosidase enzymes by transgalactosylation activity (Torres et al., 2010). These enzymes have been obtained from different organisms, such as Aspergillus oryzae, Bifidobacterium longum, Lactobacillus reuteri, Bacillus circulans, Kluyveromyces lactis, and Thermotoga maritime (Tanaka and Horiuchi, 1975; Kim et al., 2004; Chockchaisawasdee et al., 2005; Nguyen et al., 2006; Hsu et al., 2007; Li et al., 2010; Yin et al., 2017). The efficiency of GOS production using these enzymes varies depending on the source. Generally, GOS synthesis is more efficient at higher temperatures in part due to the better solubility of lactose. Therefore, $\beta$-galactosidase enzymes from thermophiles are good candidates for efficient GOS production. A yield of $52.5 \%$ (wt/wt) GOS was obtained from an initial lactose concentration of 600 $\mathrm{g} / \mathrm{L}$ using a $\beta$-galactosidase enzyme from the extreme thermophile, Sulfolobus solfataricus (Park et al., 2008), which was the highest concentration of GOS yield reported at that time.

To facilitate efficient GOS production, enzyme immobilization by entrapment, covalent binding, or ad- 
sorption have been used. Various materials have been used, such as cellulose, chitosan, alginate, and cotton cloth (Albayrak and Yang, 2002; Sakai et al., 2008; Lu et al., 2012; Chen and Duan, 2015). Most immobilized $\beta$-galactosidase enzymes function at a range of temperatures between 30 and $50^{\circ} \mathrm{C}$. However, hyperthermostable enzymes with optimal temperatures greater than $70^{\circ} \mathrm{C}$ would require materials for immobilization with a high thermostability.

The first reported immobilized thermophilic enzyme was a protease from Thermus aquaticus, which was immobilized using 3 different materials, Sepharose 4B, carboxymethyl cellulose, and controlled pore glass, with Sepharose exhibiting the greatest thermostability (Cowan and Daniel, 1982). However, this enzyme immobilization process requires activation of Sephorose with cyanogen bromide and is therefore not suitable for food applications (Wilchek and Miron, 2003). Other immobilization techniques have now been developed for thermophilic enzymes, such as agarose and chitosan (Filho et al., 2008). Both materials demonstrated efficient activity at high temperatures, but glutaraldehyde was used as a cross-linker in both cases, to physically connect the immobilization materials to the enzyme itself. However, glutaraldehyde is a biocide and exposure to it has been linked to respiratory and skin irritation (Nayebzadeh, 2007).

Previously, we developed an efficient GOS production system using the hyperthermostable $\beta$-galactosidase enzyme from $S$. solfataricus overexpressed in Lactococcus lactis using a synthetic biology approach. Rather than using purified enzyme, whole, permeabilized cells of $L$. lactis containing this enzyme were used for GOS production at $85^{\circ} \mathrm{C}$ (Yu and O'Sullivan, 2014). While efficient and cost effective, removal of the whole cells from the GOS preparation following synthesis was cumbersome, due to the need for centrifugation and filtration. The objectives of this study was to remove the recombinant DNA from the enzyme containing whole cells, and develop a suitable thermostable immobilization system to facilitate removal of the whole cells following GOS synthesis.

\section{MATERIALS AND METHODS}

\section{Bacteria, Media, and Culture Conditions}

Lactococcus lactis LM0230 (pDOLY105, pDOC23; Chandrapati and O'Sullivan, 1999; Yu and O'Sullivan, 2014) was inoculated in M17 (Becton, San Jose, CA) broth medium with $0.5 \%$ glucose and grown at $30^{\circ} \mathrm{C}$ without shaking. Both erythromycin and chloramphenicol were used at a level of $3 \mu \mathrm{g} / \mathrm{mL}$ each for L. lactis.

\section{Whole-Cell Enzyme Preparation}

Lactococcus lactis LM0230 (pDOLY105, pDOC23) was grown until an optical density (OD) at $600 \mathrm{~nm}$ of 0.7 before nisin (Sigma-Aldrich, St. Louis, MO) was added at a concentration of $1.0 \mathrm{IU} / \mathrm{mL}$ to induce enzyme production for $2.5 \mathrm{~h}$. The induced cell pellet was then washed with the same volume of ice-cold water and resuspended with a half volume of $\mathrm{POM}$ buffer (50 $\mathrm{m} M \mathrm{~K}_{2} \mathrm{HPO}_{4}, 50 \mathrm{~m} M \mathrm{KH}_{2} \mathrm{PO}_{4}$, and $1 \mathrm{mM} \mathrm{MgCl}$; $\mathrm{pH}$ 7.4). Another half volume of $100 \%$ ethanol was subsequently added to kill and permeabilize the cells. The whole cells were further incubated at room temperature for $25 \mathrm{~min}$ and centrifuged $(10,000 \times g$ for $15 \mathrm{~min}$ at $4^{\circ} \mathrm{C}$ ). The cells were then washed using 1 volume of POM buffer before resuspension in one-third volume of molecular-biology-grade water.

\section{Removal and Detection of Recombinant DNA}

An aliquot of $5 \mathrm{~mL}$ of permeabilized cells were placed in an uncovered Petri dish and exposed to UV irradiation for 30, 60, and $90 \mathrm{~s}$ in a UV Stratalinker 2400 (LabX, Midland, Canada). Subsequently, the UV-treated cells were pelleted by centrifugation and the pellets were resuspended in $500 \mu \mathrm{L}$ of molecular-biology-grade water, before disruption with $250 \mu \mathrm{L}$ of glass beads $(<600 \mu \mathrm{m}$, Sigma-Aldrich) using a bead-beater (BioSpec, Bartlesville, OK) for $1 \mathrm{~min}$ at maximum speed. An aliquot of $1 \mu \mathrm{L}$ was taken from the mixture for PCR detection to determine the efficiency of UV treatment.

The lacSt gene for hyperthermostable $\beta$-galactosidase was detected by PCR using Taq DNA polymerase (New England Biolabs, Ipswich, MA). Two oligonucleotides, LacSt forward 5'-GCGAATGCATCTAGATCCCC-3' and LacSt2 reverse 5'-CAGCTATGACCATGATTACGCC-3', were designed and synthesized for use as primers. The PCR reaction was performed using a PTC-200 thermocycle (MJ Research, Ramsey, MN) with cycling conditions consisting of an initial denaturation at $95^{\circ} \mathrm{C}$ for $5 \mathrm{~min}$, before 35 cycles of denaturation at $95^{\circ} \mathrm{C}$ for $20 \mathrm{~s}$, annealing at $50^{\circ} \mathrm{C}$ for $30 \mathrm{~s}$ and extension at $68^{\circ} \mathrm{C}$ for $90 \mathrm{~s}$, and one final extension at $68^{\circ} \mathrm{C}$ for $5 \mathrm{~min}$. The PCR reaction consisted of a buffer $(10 \mathrm{~m} M$ Tris$\mathrm{HCl}, 50 \mathrm{mM} \mathrm{KCl}$, and $1.5 \mathrm{mM} \mathrm{MgCl} 2, \mathrm{pH} 8.3), 200 \mu M$ deoxynucleotide triphosphates, $0.2 \mu M$ of each primer, $1 \mu \mathrm{L}$ of template, 0.75 units of Taq DNA polymerase, and molecular-grade water to bring the total volume to $25 \mu \mathrm{L}$.

\section{Immobilization of Whole Cells}

Whole cells $(30 \mathrm{~mL})$ were resuspended in $10 \mathrm{~mL}$ of $2 \%$ low-molecular-weight chitosan (molecular weight 
50-190 kDa; 75-85\% deacethylated; Sigma-Aldrich) in $1 \%$ acetic acid. The mixture was then added dropwise into $1 \mathrm{~L}$ of $1.5 \%$ sodium triphosphate (TPP; Thermo Fisher Scientific, Cleveland, $\mathrm{OH}$ ) using a micropipette p1000 with continuous stirring. The suspension was magnetically stirred for $1 \mathrm{~h}$ at room temperature for bead formation. The chitosan beads were washed with distilled water before use.

Alginate beads were prepared by mixing $100 \mathrm{~mL}$ of $2 \%$ (wt/vol) alginate (Sigma-Aldrich) with $30 \mathrm{~mL}$ of whole cells. This mixture was added dropwise through a micropipette (p1000) into $100 \mathrm{~mL}$ of $2 \%$ (wt/vol) $\mathrm{CaCl}_{2}$ solution with continuous stirring. The suspension was magnetically stirred for $1 \mathrm{~h}$ at room temperature. The alginate beads were washed with distilled water before use.

\section{$\beta$-Galactosidase Measurements}

$\beta$-Galactosidase activity was measured by hydrolysis of ortho-nitrophenyl- $\beta$-galactoside (ONPG). The ONPG was composed of galactose and orthonitrophenol; the latter compound turns a yellow color when cleaved from galactose and quantitatively reflects enzyme activity. Both immobilized cells and free wholecell enzymes were assayed at $85^{\circ} \mathrm{C}$, in $1 \mathrm{~mL}$ of $0.05 \mathrm{M}$ sodium acetate buffer ( $\mathrm{pH} 6)$. An aliquot of $200 \mu \mathrm{L}$ of $4 \mathrm{mg} / \mathrm{mL}$ ONPG was added to the reaction mixture. The reaction was stopped by adding $500 \mu \mathrm{L}$ of a $1 \mathrm{M} \mathrm{Na}_{2} \mathrm{CO}_{3}$ solution at room temperature when sufficient yellow color was developed and the number of minutes for the reaction was recorded. The color was measured spectrophotometrically at $420 \mathrm{~nm}$ by the released ortho-nitrophenol. Units of enzyme activity was calculated using the following equation: units $=1,000$ $\times\left(\mathrm{OD}_{420 \mathrm{~nm}}-1.75 \times \mathrm{OD}_{550 \mathrm{~nm}}\right) /($ volume of cells used $\times$ time of reaction $\times \mathrm{OD}_{600 \mathrm{~nm}}$ of cells used), as proposed by Miller (1972).

\section{GOS Synthesis and Detection}

An aliquot of 5 beads containing whole cells of thermostable $\beta$-galactosidase were added to a reaction mixture, in which $5 \%$ lactose was dissolved in $0.05 \mathrm{M}$ sodium acetate buffer ( $\mathrm{pH} 6)$. The reaction mixture was incubated at $85^{\circ} \mathrm{C}$ for $25 \mathrm{~h}$. The reaction was terminated by incubating the reaction mixture at $4^{\circ} \mathrm{C}$. The sample was filtered through a $0.22-\mu \mathrm{m}$ membrane and diluted 4,000-fold using sterile ammonium acetate buffer $(\mathrm{pH}$ 8.4) for further analysis. An aliquot of $10 \mu \mathrm{L}$ of sample was used for ultra-high-performance liquid chromatography (UPLC)-MS analysis. The conditions for the UPLC-MS were as previously described (Yu and O'Sullivan, 2014). The transgalactosylation activity was determined by the production of tri-oligosaccharides and tetra-oligosaccharides. The lactose conversion rate is (tri-oligosaccharides + tetra-oligosaccharides) concentration/initial lactose concentration.

\section{Thermostability of the Encapsulated Whole-Cell Enzyme}

The thermostability for both free whole-cell and immobilized whole-cell enzymes was analyzed by incubating 1-mL samples in Eppendorf tubes at $100^{\circ} \mathrm{C}$. Samples were withdrawn for analysis every $3 \mathrm{~min}$ and $\beta$-galactosidase activity was quantified at $85^{\circ} \mathrm{C}, \mathrm{pH} 6$.

\section{Reusability of Chitosan-Encapsulated Beads}

The immobilized $\beta$-galactosidase beads were used for successive batches of GOS production. After one cycle, the reaction medium was discarded and separated from the immobilized enzyme. The immobilized enzyme was then incubated again with fresh medium to start another cycle for GOS production. Each cycle lasted for $24 \mathrm{~h}$. Both hydrolysis and transgalactosylation activities were measured to determine the reusability.

\section{Scanning Electron Microscopy}

The topology of the chitosan beads was evaluated by scanning electron microscopy. Before using scanning electron microscopy, chitosan beads were dried using different concentrations of ethanol for moisture removal. Beads were immersed in an increasing ethanol/ water mixtures ranging from 30 to $100 \%$ ethanol. The beads were left for $10 \mathrm{~min}$ in each solution and then dried at $30^{\circ} \mathrm{C}$ for $5 \mathrm{~h}$. Dried beads were coated with electronic conductive materials, consisting of $60 \%$ gold and $40 \%$ palladium, before observation. Micrographs were taken using a 4700 Scanning Electron Microscope (Hitachi, Krefeld, Germany).

\section{RESULTS}

\section{Immobilization of Whole Cells of Lactococcus lactis Containing a Hyperthermostable $\beta$-Galactosidase}

In a previous study, we developed a cell-based technology to overproduce GOS using a hyperthermostable $\beta$-galactosidase enzyme (Yu and O'Sullivan, 2014). To facilitate easy separation from the reaction mixture, the whole-cell enzyme needed to be encapsulated in a thermostable and food-grade material. Both alginate and chitosan have been used for food applications as coating materials, dietary fiber, and food stabilizers (Gennadios et al., 1997; Shahidi et al., 1999; Brown- 
lee et al., 2005; Rinaudo, 2006). In addition, previous studies have successfully immobilized thermostable enzymes, such as $\alpha$-amylase and $\beta$-glycosidase, for applications up to $95^{\circ} \mathrm{C}$, using these 2 materials (D'Auria et al., 1996; Tee and Kaletunç, 2009). Therefore, both alginate and chitosan were evaluated to immobilize the hyperthermostable $\beta$-galactosidase enzyme using $\mathrm{CaCl}_{2}$ and tripolyphosphate as crosslinkers, respectively. The entrapped whole-cell enzyme beads were circular in shape with a diameter of $\sim 2.5 \mathrm{~mm}$ radius.

\section{Recombinant DNA Removal from the Whole-Cell Enzyme}

Plasmid pDOLY105 with the recombinant lacSt gene was previously transformed into L. lactis for hyperthermostable $\beta$-galactosidase enzyme production. Given that only the enzyme is needed for GOS production, UV exposure was used to eliminate the recombinant DNA below the level of detection by PCR. The synthetic lacSt gene was not detected after 30,60, and $90 \mathrm{~s}$ of UV exposure (Figure 1). Therefore, the 30-s UV treatment was found to be adequate to degrade the recombinant DNA below the level of detection by PCR. It was also found that the treated enzyme retained more than $97 \%$ of $\beta$-galactosidase activity. This indicated that UV treatment had minimum effect on the $\beta$-galactosidase enzyme activity and the UV-treated whole cells were suitable for immobilization.

\section{Effect of Temperature and $\mathrm{pH}$ on $\beta$-Galactosidase Hydrolysis and Transgalactosylation Using Both Free and Immobilized Whole-Cell Enzymes}

The effect of temperature on $\beta$-galactosidase hydrolysis was determined by assaying both free whole cells and immobilized whole cells (in alginate and chitosan) in sodium acetate buffer $(\mathrm{pH} 6)$ at temperatures ranging from 70 to $95^{\circ} \mathrm{C}$, whereas the optimum $\mathrm{pH}(4-6)$ was evaluated in the same sodium acetate buffer at $85^{\circ} \mathrm{C}$. Entrapped enzymes (both alginate and chitosan beads) exhibited optimum hydrolysis activities at similar conditions $\left(\mathrm{pH} 6\right.$ and $\left.90^{\circ} \mathrm{C}\right)$ to the free whole-cell enzyme (Figure 2). No significant difference was observed over the temperature range between free whole cells and entrapped cells, but at the lowest $\mathrm{pH}$ tested (5.0), the relative hydrolysis activity was lower for the free whole cells.

As the alginate beads swelled dramatically during prolonged exposure to these high temperatures, only the chitosan beads were evaluated for GOS production (transgalactosylation activity) at 80 to $95^{\circ} \mathrm{C}$ and various $\mathrm{pH}$ values (4-6) using a $5 \%$ lactose solution over $25 \mathrm{~h}$. As Figure 3 illustrates, the optimum $\mathrm{pH}$ for
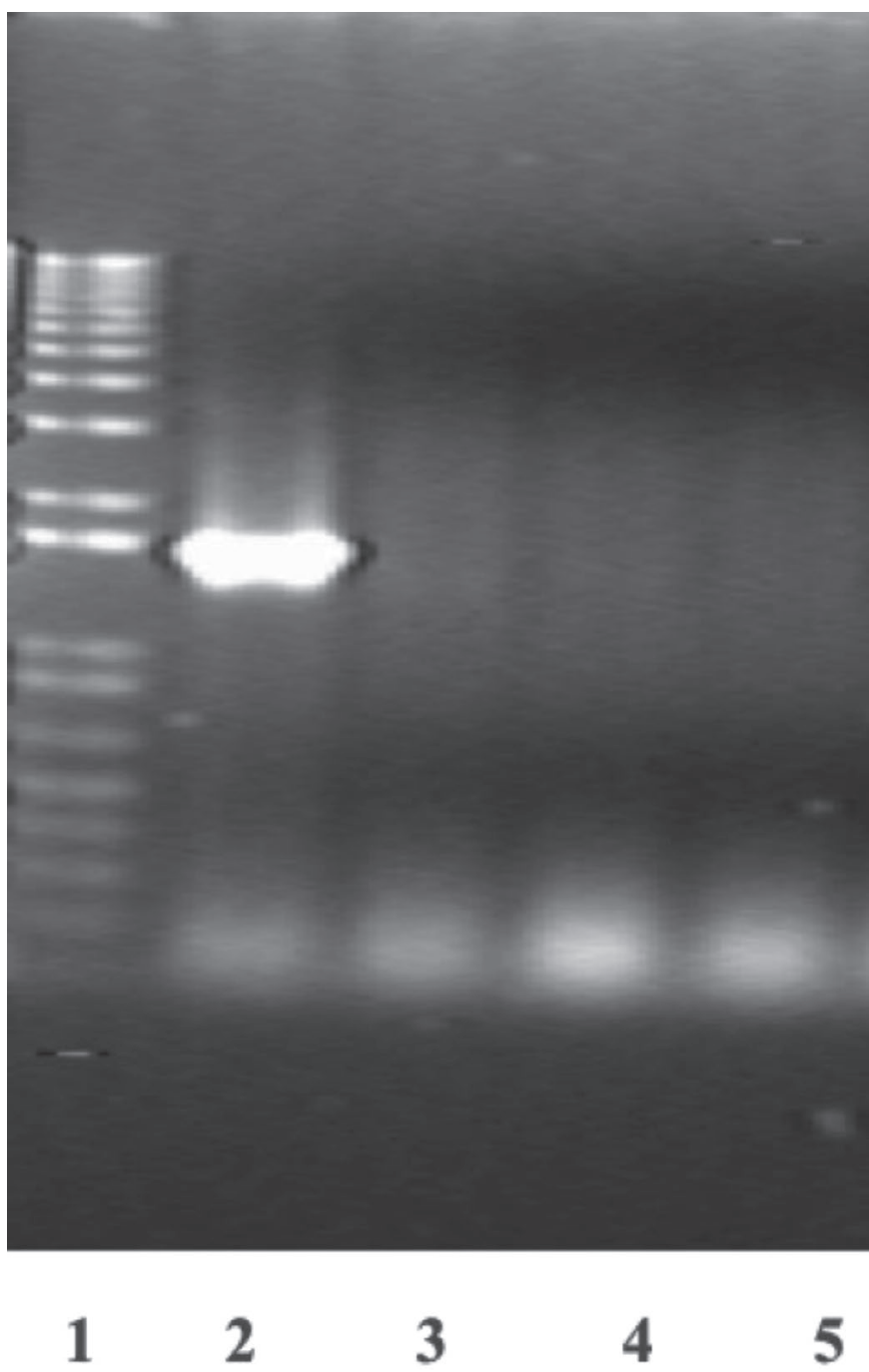

Figure 1. Effect of UV on genetically modified genes. Lanes: 1, 1-kb ladder; 2, PCR products using the whole cells without UV treatment as a template; 3 , PCR products using the whole cells with 30-s UV treatment as a template; $4, \mathrm{PCR}$ products using the whole cells with $60-\mathrm{s}$ UV treatment as a template; 5 , PCR products using the whole cells with $90-\mathrm{s}$ UV treatment as a template.

GOS synthesis using the immobilized enzymes was 5.5 and the transgalactosylation activity dropped significantly at $\mathrm{pH} 6$. In addition, the optimum temperature for GOS synthesis using the immobilized enzymes was $90^{\circ} \mathrm{C}$, with a noticeable drop off at $95^{\circ} \mathrm{C}$.

\section{Effect of Initial Lactose Concentration on Tri- and Tetra-GOS Production}

The GOS production was evaluated using lactose concentration from 5 to $50 \%$ at $90^{\circ} \mathrm{C}$ and $\mathrm{pH} 6$ for 25 h. The total GOS production increased with increasing lactose concentrations up to a $40 \%$ initial concentration, resulting in $\sim 150 \mathrm{~g} / \mathrm{L}$ of GOS, not including disac- 
charide GOS moieties, which were not distinguishable from lactose by the MS methodology used in this study (Figure 4). However, the lactose conversion rate into GOS was highest for the lowest starting lactose of $5 \%$, which resulted in almost $60 \%$ conversion into tri- and tetra-GOS. Specifically, $3 \mathrm{~g} / 100 \mathrm{~mL}$ of total tri- and tetra-GOS was produced from $5 \mathrm{~g} / 100 \mathrm{~mL}$ of initial lactose.

\section{Thermostability and Reusability of the Chitosan- Immobilized Whole-Cell Hyperthermostable $\beta$-Galactosidase Enzyme}

The thermostability of the immobilized whole-cell enzyme was determined by investigating the effect of incubation at $100^{\circ} \mathrm{C}$ on its subsequent hydrolysis activity. The immobilized enzyme showed a higher ther-
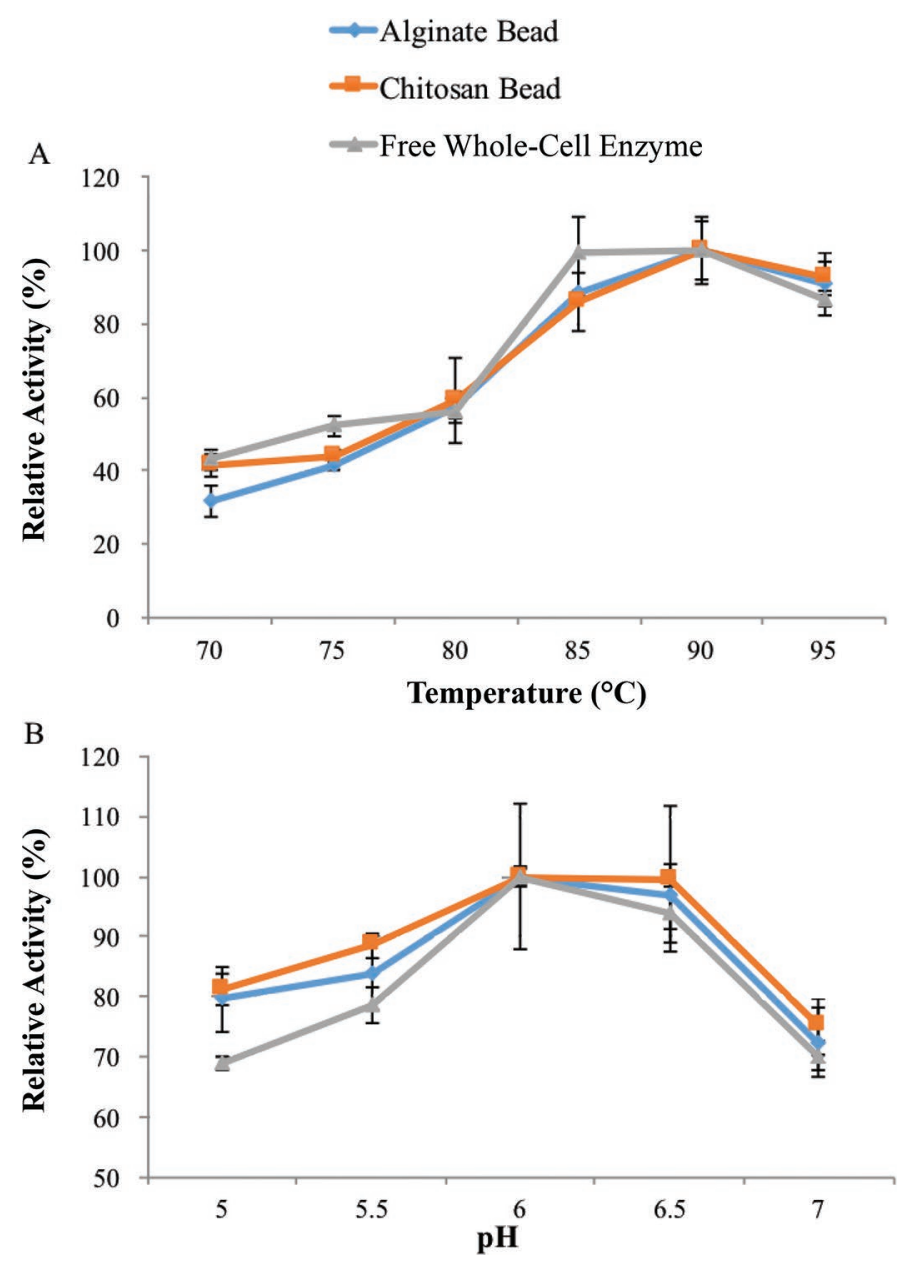

Figure 2. Effect of temperature and $\mathrm{pH}$ on $\beta$-galactosidase activity using both free whole-cell enzyme and immobilized enzyme. The error bars indicate SD $(\mathrm{n}=3)$. Relative activities are the ratio of $\beta$-galactosidase activity under different conditions to the highest $\beta$-galactosidase activities for free whole-cell enzyme and chitosan-immobilized enzyme, respectively. Color version available online. mostability at $100^{\circ} \mathrm{C}$ than the free whole-cell enzyme (Figure 5). After $18 \mathrm{~min}$ of incubation at $100^{\circ} \mathrm{C}$, the immobilized whole-cell enzyme still retained $\sim 50 \%$ activity, whereas the free whole-cell enzyme lost more than $90 \%$ of its $\beta$-galactosidase activity.

The reusability of the immobilized whole-cell enzyme was examined using both a $\beta$-galactosidase assay for hydrolysis activity and GOS synthesis for transgalactosylation activity. Both methods showed similar profiles for the recycling efficiency (Figure 6). The immobilized enzyme beads retained $\sim 50 \%$ activity with $40 \%$ of initial lactose after 2 cycles of GOS production and exhibited $\sim 20 \%$ of both hydrolysis and transgalactosylation activities after 6 cycles of reuse.

\section{Surface Characterization of the Chitosan Beads}

The topology of the chitosan bead surface was investigated using scanning electron microscopy. The surface
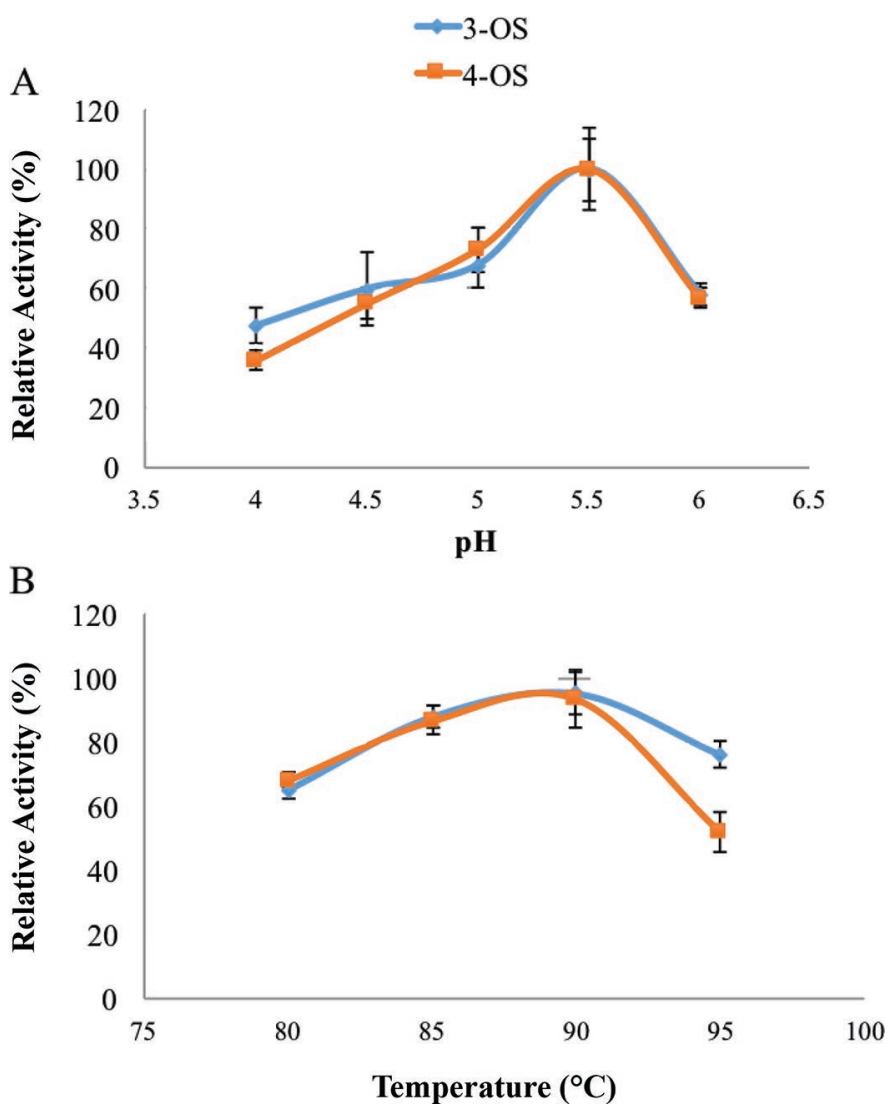

Figure 3. Effect of $\mathrm{pH}$ and temperature on galacto-oligosaccharide (GOS) synthesis using immobilized enzyme. The effect of $\mathrm{pH}$ on GOS production was investigated in a range from 4 to 6 with $5 \%$ lactose as substrate at $85^{\circ} \mathrm{C}$ for $25 \mathrm{~h}$. The effect of temperature on GOS production was investigated in a range from 80 to $95^{\circ} \mathrm{C}\left(80,85,90,95^{\circ} \mathrm{C}\right)$ with $5 \%$ lactose as substrate at $\mathrm{pH} 6$ for $25 \mathrm{~h}$. 3 -OS = tri-oligosaccharides; 4 -OS $=$ tetra-oligosaccharides. The error bars indicated SD $(\mathrm{n}=2)$. Color version available online. 


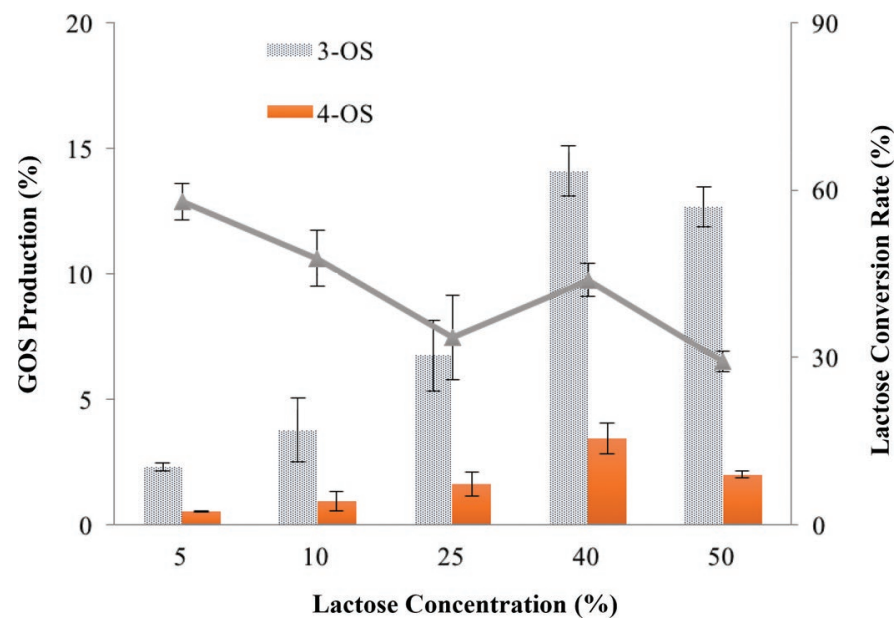

Figure 4. Effect of initial lactose concentration using immobilized enzyme. The effect of initial lactose on galacto-oligosaccharide (GOS) production was investigated in a range of $5,10,25,40$, and $50 \%$ lactose as substrate at $90^{\circ} \mathrm{C}$ for $25 \mathrm{~h}$. 3-OS = tri-oligosaccharides; 4-OS $=$ tetra-oligosaccharides. The error bars represent SD $(n=2)$. Color version available online.

of the beads was rough with small holes visible on the surface (Figure 7). The average diameter for each bead was around $1 \mathrm{~mm}$, with the reduced size occurring due to a dehydration process during scanning electron microscopy preparation.

\section{DISCUSSION}

Lactococcus lactis is one of the most utilized foodgrade lactic acid bacteria in food fermentations worldwide (Leroy and De Vuyst, 2004). The advent of synthetic biology has now enabled approaches to be designed that can enable exotic enzymes to be overex-

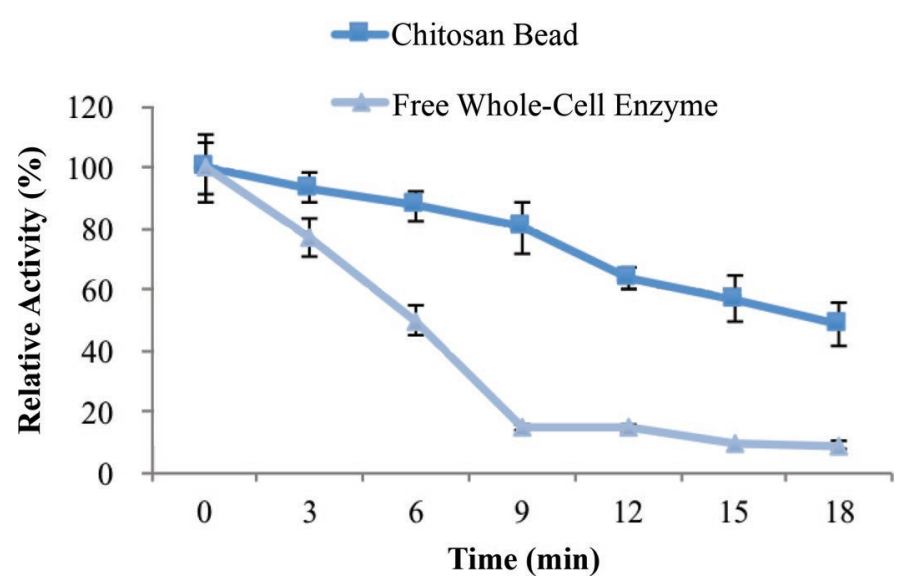

Figure 5. Effect of immobilization of the thermostability. The thermostability of the immobilized enzyme was determined by high temperature $\left(100^{\circ} \mathrm{C}\right)$ incubation and $\beta$-galactosidase assay. The error bars represent $\mathrm{SD}(\mathrm{n}=3)$. Color version available online. pressed in this host. We have previously overexpressed a $\beta$-galactosidase enzyme from an extreme hyperthermophilic organism for efficient GOS production, and in this study we have converted this into a food-grade and reusable technology for GOS production. This involved immobilizing the whole cells containing this enzyme in chitosan, which is a thermostable matrix that can be readily removed following GOS production. Although immobilization techniques have previously been developed for GOS production, none of them produce GOS under extreme high temperatures in a food-grade approach (Zheng et al., 2006; Hsu et al., 2007; Sakai et al., 2008; Neri et al., 2009; Chen and Duan, 2015). In this study, the chitosan-immobilized whole-cell enzyme was utilized at $90^{\circ} \mathrm{C}$ and $\mathrm{pH} 5.5$ for $25 \mathrm{~h}$ to convert solutions of various concentrations of lactose into GOS. The use of alginate-based beads for this purpose resulted in a loss of part of the gel network under these conditions, indicating that this material, which is commonly used for immobilization purposes, is not suitable for very high temperature uses.
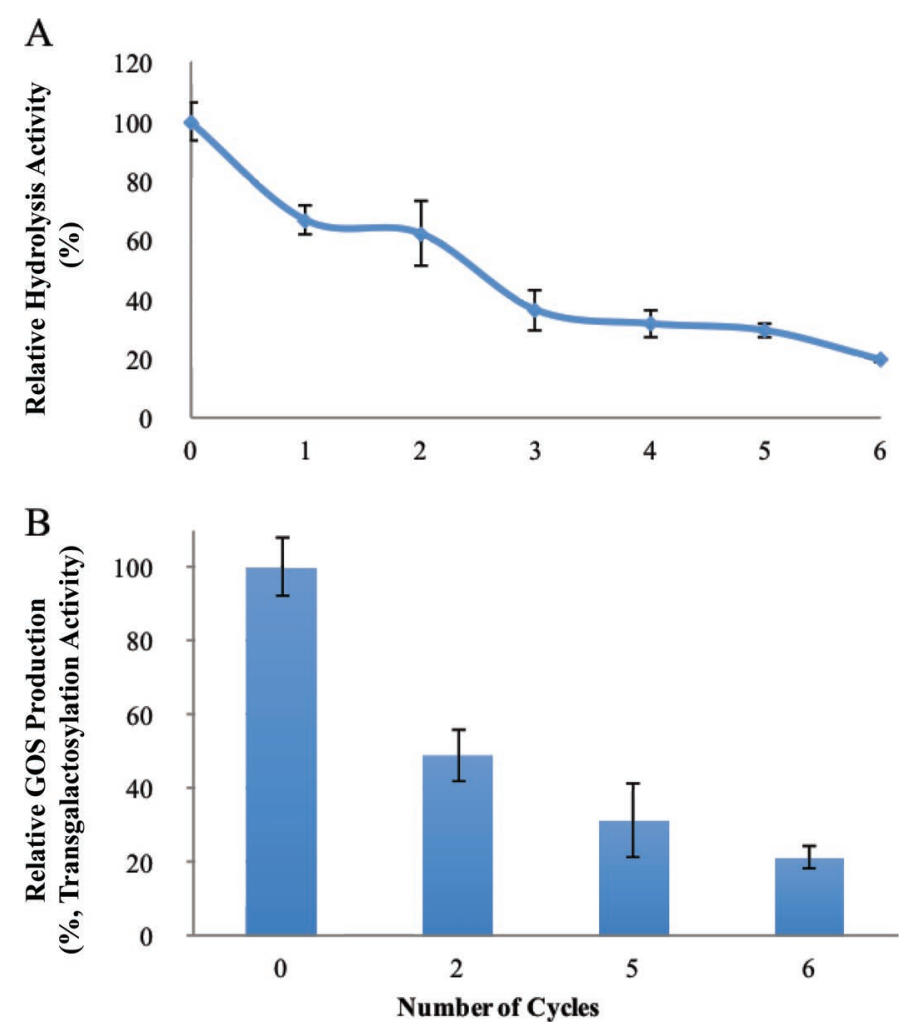

Figure 6. Effect of immobilization on reusability. The reusability of immobilized enzyme was examined using both $\beta$-galactosidase assay for hydrolysis activity (A) and for transgalactosylation activity using an initial lactose concentration of $40 \%$ for galacto-oligosaccharide (GOS) synthesis (B). The maximum (100\%) amount of GOS produced was $150 \mathrm{~g} / \mathrm{L}$ of tri- and tetra-GOS moieties. The error bars represent $\mathrm{SD}(\mathrm{n}=2)$. Color version available online. 


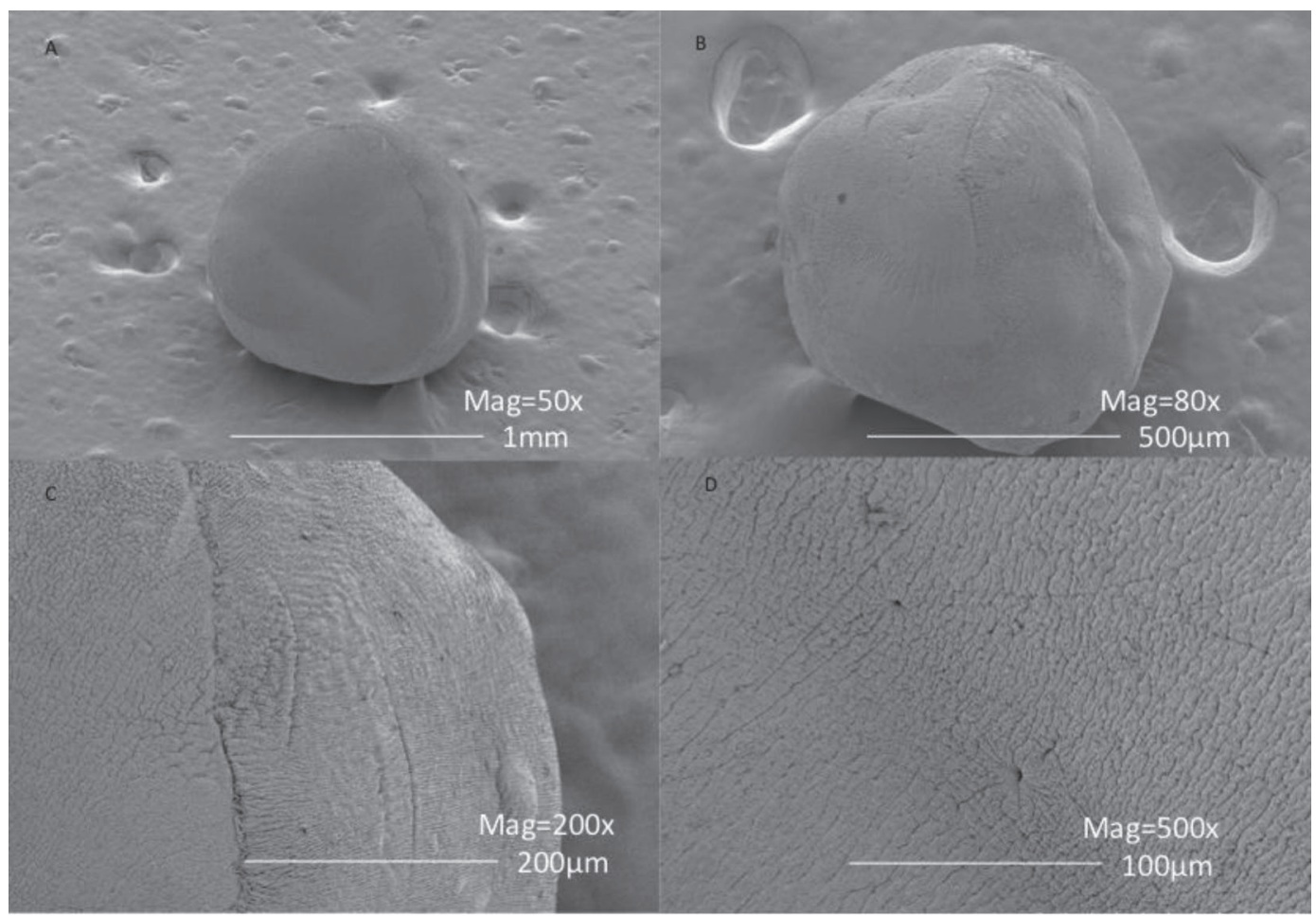

Figure 7. Scanning electron micrographs. (A), (B), (C), and (D) illustrate the surface of the chitosan-immobilized enzyme. Each picture was observed under different magnifications (Mag) of $50 \times, 80 \times, 200 \times$, and $500 \times$.

The different performances of these 2 immobilization materials can be explained by their chemical structures, which react differently under the conditions used for GOS production. Alginate is composed of $\beta$-Dmannuronate $(\mathrm{M})$ and $\alpha$-L-guluronate $(\mathrm{G})$ residues, which are $[1 \rightarrow 4]$ linked. The $G$ component is involved in gel formation with divalent ions, such as $\mathrm{Ca}^{2+}$ in the bead formation conditions used in this study (Lee and Mooney, 2012). Alginate can be easily gelled when the $\mathrm{Ca}^{2+}$ binds to different $\mathrm{G}$ blocks, resulting in a gel network, but can be disrupted when the divalent ions are replaced by monovalent metal ions (Figure 8). This results in uptake of water and bead swelling (Bajpai and Sharma, 2004). In this study, GOS was synthesized in sodium acetate buffer, in which the $\mathrm{Na}^{+}$ions can interact with the alginate gel network and gradually replace the $\mathrm{Ca}^{2+}$ ions, reducing the ionic strength causing loss of structure and swelling. However, the chitosan beads behaved differently under these conditions. Chitosan is composed of $\beta$-[1 $\rightarrow 4]$-linked $N$-acetyl-D-glucosamine $(\mathrm{N})$ and D-glucosamine $(\mathrm{G})$ residues. It is produced from chitin via deacetylation and fragmentation into different sizes. The gel network of chitosan was generated via ionic interaction with the cross-linking agent, TPP. Chitosan becomes soluble in acetic acid (low $\mathrm{pH})$, resulting in the ammonia group of the $\mathrm{G}$ residue becoming ionized, which then replaces the sodium ions of sodium TPP to form a gel (Figure 8). This explains why the chitosan beads showed a higher stability during the GOS synthesis conditions used in this study.

When the free whole-cell $\beta$-galactosidase enzyme was used for GOS production, the optimum conditions were found to be $\mathrm{pH} 6$ and $85^{\circ} \mathrm{C}$ (Yu and O'Sullivan, 2014). While using chitosan-entrapped whole-cell enzyme, the optimum conditions changed slightly to $\mathrm{pH} 5.5$ and $90^{\circ} \mathrm{C}$. This change is consistent with some previous studies that found the optimum temperature and $\mathrm{pH}$ of immobilized enzymes were different from the free enzymes (Zhou and Chen, 2001). The thermostability of the immobilized enzyme was also increased (Figure 5 ), illustrating the protective effect of the chitosan for the whole-cell enzyme. This increase in thermostability for immobilized enzymes has also been found in previous studies (Ladero et al., 2003; Rhimi et al., 2010).

In this study, a maximum GOS production of 150 $\mathrm{g} / \mathrm{L}$ was obtained from $40 \%$ starting lactose using the immobilized whole cells containing $\beta$-galactosidase from S. solfataricus. Although this is somewhat less than the $197 \mathrm{~g} / \mathrm{L}$ we previously reported for the free whole cells of this enzyme, the reduction may be due to fewer whole cells present in the beads compared with the free whole cells used. Other studies using encapsu- 
lated $\beta$-galactosidase enzymes from different organisms also produced similar yields (Table 1 ).

When GOS was produced with the immobilized whole-cell enzyme using different initial concentrations of lactose $(5-50 \%)$, the highest production of tri- and tetra-GOS was found with $40 \%$ initial lactose, which was consistent with our previous study using the whole-cell enzyme (Yu and O'Sullivan, 2014). A similar optimum initial lactose concentration was observed for GOS production using other $\beta$-galactosidase enzymes from B. longum and Penicillium expansum (Hsu et al., 2007). However, GOS production using the $\beta$-galactosidase enzyme from Aspergillus oryzae showed a higher amount of GOS using 50\% initial lactose, illustrating that enzymes from different sources can have different substrate saturation levels.

Recombinant DNA technology can be used to produce natural food ingredients that are free of any recombinant DNA. Chymosin, from the abomasum of a suckling young bovine, is a well-known example that is produced via recombinant DNA technology in Escherichia coli, yeast, and fungi and is used worldwide in commercial cheese manufacture (Mohanty et al., 1999). This was the first food ingredient produced via recombinant DNA technology to be approved by the Food and Drug Administration in 1990, and its use in food production does not constitute a genetically modified process under current labeling guidelines as the enzyme does not contain any genetically modified materials. In this study the recombinant DNA in the whole-cell enzyme was degraded by UV to below the level detectable by PCR, which is the standard currently used in foods to differentiate a GM food from and GM-free food.

In conclusion, a chitosan-based immobilized hyperthermostable $\beta$-galactosidase enzyme was developed, and this enabled efficient GOS production for foodgrade use. This technology enabled more than $60 \%$ of the lactose in a $5 \%$ initial lactose solution, which is similar to cheese whey, to be converted into tri- and tetra-GOS products in addition to dimer GOS products that were not quantified. Upon removal of the beads following GOS production, the final GOS-enriched product was free of any recombinant material and therefore suitable for food-grade applications.
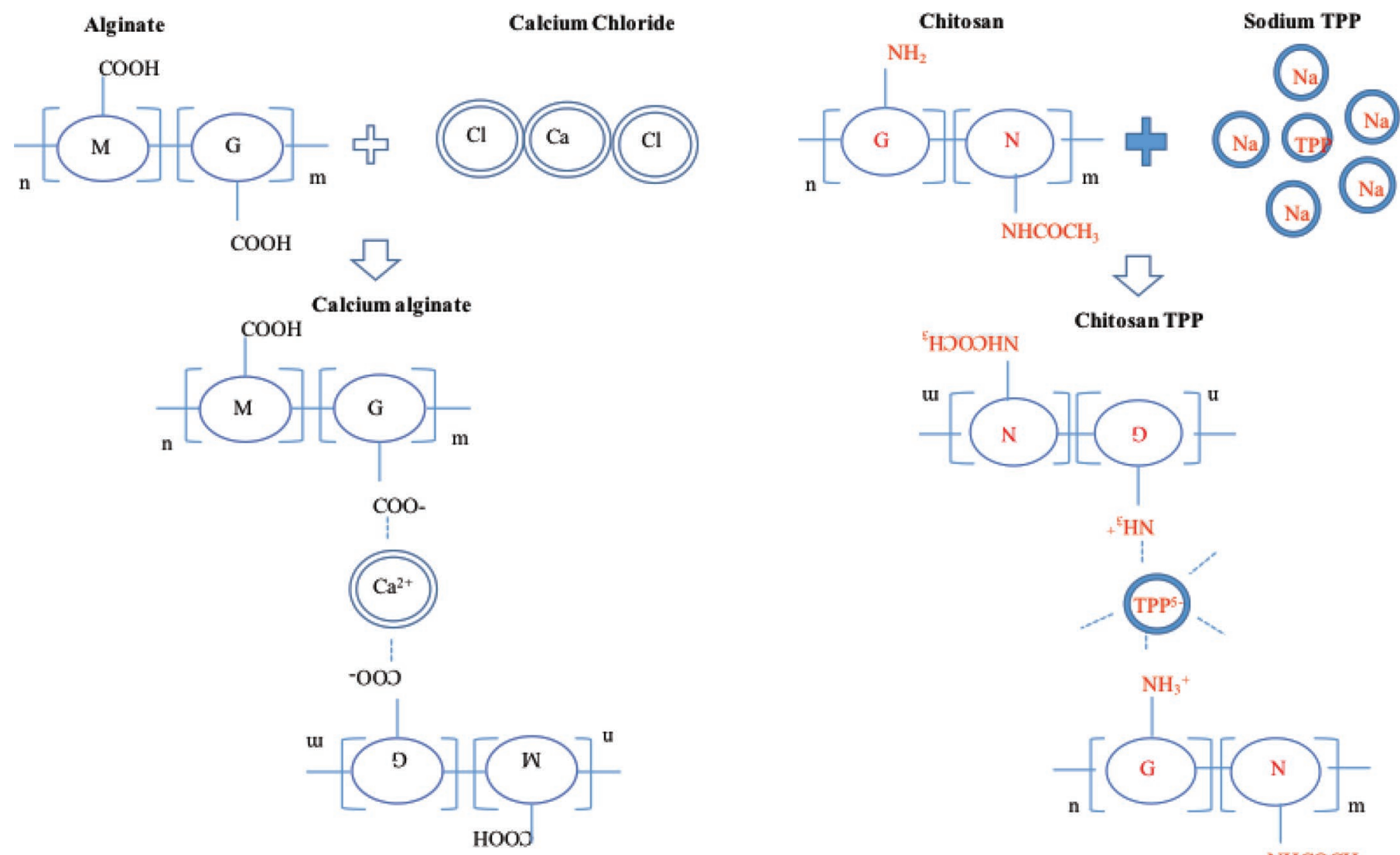

Figure 8. Gel network formation process by alginate and calcium chloride, chitosan, and sodium triphosphate (TPP). Alginate: $\mathrm{m}=\beta$-Dmannuronate (M), $\mathrm{G}=\alpha$-L-gluronate. Chitosan: $\mathrm{G}=$ D-glucosamine, $\mathrm{n}=N$-acetyl-D-glucosamine (N). Color version available online. 


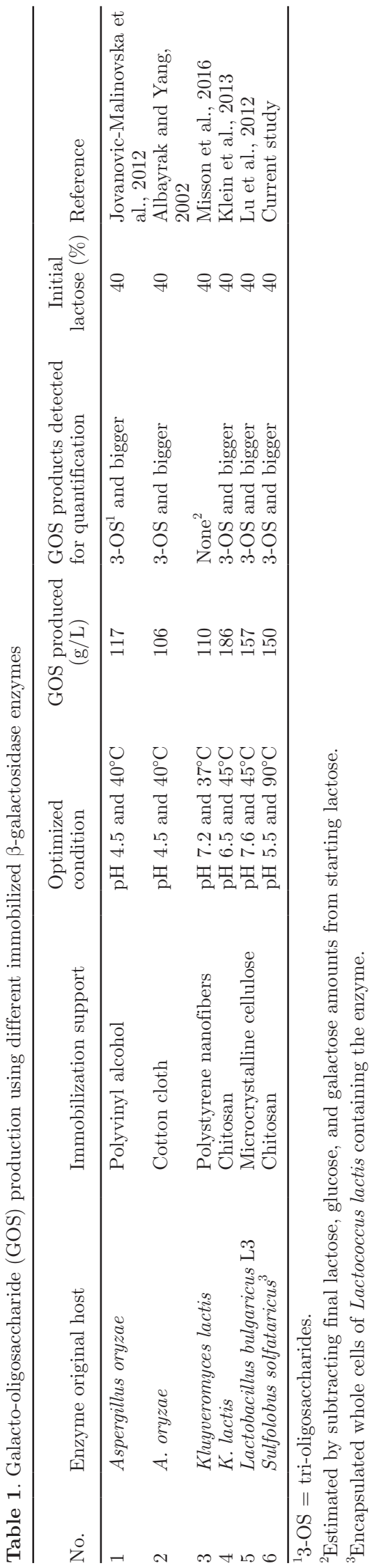

\section{ACKNOWLEDGMENTS}

We thank Midwest Dairy Association (St. Paul, MN) for supporting this project. Special thanks to Stephan Harvey (Center for Mass Spectrometry and Proteomics, University of Minnesota, St. Paul) for help with the UPLC-MS.

\section{REFERENCES}

Albayrak, N., and S. T. Yang. 2002. Production of galacto-oligosaccharides from lactose by Aspergillus oryzae beta-galactosidase immobilized on cotton cloth. Biotechnol. Bioeng. 77:8-19. https:// doi.org/10.1002/bit.1195.

Bajpai, S. K., and S. Sharma. 2004. Investigation of swelling/degradation behaviour of alginate beads crosslinked with $\mathrm{Ca}^{2+}$ and $\mathrm{Ba}^{2+}$ ions. React. Funct. Polym. 59:129-140. https://doi.org/10.1016/j reactfunctpolym.

Brownlee, I. A., A. Allen, J. P. Pearson, P. W. Dettmar, M. E. Havler M. R. Atherton, and E. Onsøyen. 2005. Alginate as a source of dietary fiber. Crit. Rev. Food Sci. Nutr. 45:497-510. https://doi .org/10.1080/10408390500285673.

Chandrapati, S., and D. J. O'Sullivan. 1999. Nisin independent induction of the nisA promoter in Lactococcus lactis during growth in lactose or galactose. FEMS Microbiol. Lett. 170:191-198. https:// doi.org/10.1016/S0378-1097(98)00531-X.

Chen, S. C., and K. J. Duan. 2015. Production of galactooligosaccharides using $\beta$-galactosidase immobilized on chitosan-coated magnetic nanoparticles with tris (hydroxymethyl) phosphine as an optional coupling agent. Int. J. Mol. Sci. 16:12499-12512. https:// doi.org/10.3390/ijms160612499.

Chockchaisawasdee, S., V. I. Athanasopoulos, K. Niranjan, and R. A. Rastall. 2005. Synthesis of galacto-oligosaccharide from lactose using beta-galactosidase from Kluyveromyces lactis: Studies on batch and continuous UF membrane-fitted bioreactors. Biotechnol. Bioeng. 89:434-443. https://doi.org/10.1002/bit.20357.

Cowan, D. A., and R. M. Daniel. 1982. The properties of immobilized caldolysin, a thermostable protease from an extreme thermophile. Biotechnol. Bioeng. 24:2053-2061. https://doi.org/10.1002/bit .260240912.

D'Auria, S., F. Pellino, F. La Cara, R. Barone, M. Rossi, and R. Nucci. 1996. Immobilization on chitosan of a thermophilic $\beta$-glycosidase expressed in Saccharomyces cerevisiae. Appl. Biochem. Biotechnol. A Enzym. Eng. Biotechnol. 61:157-166.

Davis, L. M. G., I. Martínez, J. Walter, and R. Hutkins. 2010. A dose dependent impact of prebiotic galactooligosaccharides on the intestinal microbiota of healthy adults. Int. J. Food Microbiol. 144:285-292. https://doi.org/10.1016/j.ijfoodmicro.2010.10.007.

Depeint, F., G. Tzortzis, J. Vulevic, K. I'Anson, and G. R. Gibson. 2008. Prebiotic evaluation of a novel galactooligosaccharide mixture produced by the enzymatic activity of Bifidobacterium bifidum NCIMB 41171, in healthy humans: A randomized, doubleblind, crossover, placebo-controlled intervention study. Am. J. Clin. Nutr. 87:785-791.

Filho, M., B. C. Pessela, C. Mateo, A. V. Carrascosa, R. FernandezLafuente, and J. M. Guisán. 2008. Immobilization-stabilization of an $\alpha$-galactosidase from Thermus sp. strain T2 by covalent immobilization on highly activated supports: Selection of the optimal immobilization strategy. Enzyme Microb. Technol. 42:265-271. https://doi.org/10.1016/j.enzmictec.2007.10.006.

Gennadios, A., M. A. Hanna, and L. B. Kurth. 1997. Application of edible coatings on meats, poultry and seafoods: A review. Food Sci. Technol. Technol. 30:337-350. https://doi.org/10.1006/fstl .1996 .0202 .

Hsu, C. A., S. L. Lee, and C. C. Chou. 2007. Enzymatic production of galactooligosaccharides by beta-galactosidase from Bifidobacterium longum BCRC 15708. J. Agric. Food Chem. 55:2225-2230. https://doi.org/10.1021/jf063126+. 
Jovanovic-Malinovska, R., P. Fernandes, E. Winkelhausen, and L. Fonseca. 2012. Galacto-oligosaccharides synthesis from lactose and whey by $\beta$-galactosidase immobilized in PVA. Appl. Biochem. Biotechnol. 168:1197-1211. https://doi.org/10.1007/s12010-012-9850 -1 .

Kim, C. S., E. S. Ji, and D. K. Oh. 2004. Characterization of a thermostable recombinant beta-galactosidase from Thermotoga maritima. J. Appl. Microbiol. 97:1006-1014. https://doi.org/10.1111/j.1365 $-2672.2004 .02377 . x$

Klein, M. P., L. P. Fallavena, J. D. N. Schöffer, M. A. Z. Ayub, R. C. Rodrigues, J. L. Ninow, and P. F. Hertz. 2013. High stability of immobilized $\beta$-d-galactosidase for lactose hydrolysis and galactooligosaccharides synthesis. Carbohydr. Polym. 95:465-470. https://doi .org/10.1016/j.carbpol.2013.02.044.

Ladero, M., M. T. Perez, A. Santos, and F. Garcia-Ochoa. 2003. Hydrolysis of lactose by free and immobilized $\beta$-galactosidase from Thermus sp. strain T2. Biotechnol. Bioeng. 81:241-252. https:// doi.org/10.1002/bit.10466.

Lee, K. Y., and D. J. Mooney. 2012. Alginate: Properties and biomedical applications. Prog. Polym. Sci. 37:106-126. https://doi.org/10 .1016/j.progpolymsci.2011.06.003.

Leroy, F., and L. De Vuyst. 2004. Lactic acid bacteria as functional starter cultures for the food fermentation industry. Trends Food Sci. Technol. 15:67-78. https://doi.org/10.1016/j.tifs.2003.09.004.

Li, W., Y. Sun, H. Ye, and X. Zeng. 2010. Synthesis of oligosaccharides with lactose and N-acetylglucosamine as substrates by using $\beta$-d-galactosidase from Bacillus circulans. Eur. Food Res. Technol. 231:55-63. https://doi.org/10.1007/s00217-010-1254-2.

Lu, L., S. Xu, R. Zhao, D. Zhang, Z. Li, Y. Li, and M. Xiao. 2012. Synthesis of galactooligosaccharides by CBD fusion $\beta$-galactosidase immobilized on cellulose. Bioresour. Technol. 116:327-333. https:// doi.org/10.1016/j.biortech.2012.03.108.

Miller, J. nH. 1972. Experiments in Molecular Genetics. Cold Spring Harbor Laboratory Press, Cold Spring Harbor, NY. 433:352-355. papers2://publication/uuid/ 28F839D6-A272-4D50-9114-D2769DE72B38.

Misson, M., S. Dai, B. Jin, B. H. Chen, and H. Zhang. 2016. Manipulation of nanofiber-based $\beta$-galactosidase nanoenvironment for enhancement of galacto-oligosaccharide production. J. Biotechnol. 222:56-64. https://doi.org/10.1016/j.jbiotec.2016.02.014.

Mohanty, A. K., U. K. Mukhopadhyay, S. Grover, and V. K. Batish. 1999. Bovine chymosin: Production by rDNA technology and application in cheese manufacture. Biotechnol. Adv. 17:205-217. https://doi.org/10.1016/S0734-9750(99)00010-5.

Nayebzadeh, A. 2007. The effect of work practices on personal exposure to glutaraldehyde among health care workers. Ind. Health 45:289-295. https://doi.org/10.2486/indhealth.45.289.

Neri, D. F. M., V. M. Balcao, F. O. Q. Dourado, J. M. B. Oliveira, L. B. Carvalho, and J. A. Teixeira. 2009. Galactooligosaccharides production by $\beta$-galactosidase immobilized onto magnetic polysiloxane-polyaniline particles. React. Funct. Polym. 69:246-251. https://doi.org/10.1016/j.reactfunctpolym.2009.01.002.

Nguyen, T. H., B. Splechtna, M. Steinböck, W. Kneifel, H. P. Lettner, K. D. Kulbe, and D. Haltrich. 2006. Purification and characterization of two novel $\beta$-galactosidases from Lactobacillus reuteri. J. Agric. Food Chem. 54:4989-4998. https://doi.org/10.1021/ jf053126u.

Park, H. Y., H. J. Kim, J. K. Lee, D. Kim, and D. K. Oh. 2008. Galactooligosaccharide production by a thermostable $\beta$-galactosidase from Sulfolobus solfataricus. World J. Microbiol. Biotechnol. 24:1553-1558. https://doi.org/10.1007/s11274-007-9642-x.

Rhimi, M., A. Boisson, M. Dejob, S. Boudebouze, E. Maguin, R. Haser, and N. Aghajari. 2010. Efficient bioconversion of lactose in milk and whey: Immobilization and biochemical characterization of a $\beta$-galactosidase from the dairy Streptococcus thermophilus LMD9 strain. Res. Microbiol. 161:515-525. https://doi.org/10.1016/j .resmic.2010.04.011.

Rinaudo, M. 2006. Chitin and chitosan: Properties and applications. Prog. Polym. Sci. 31:603-632. https://doi.org/10.1016/j .progpolymsci.2006.06.001.

Sakai, T., H. Tsuji, S. Shibata, K. Hayakawa, and K. Matsumoto. 2008. Repeated-batch production of galactooligosaccharides from lactose at high concentration by using alginate-immobilized cells of Sporobolomyces singularis YIT 10047. J. Gen. Appl. Microbiol. 54:285-293. https://doi.org/10.2323/jgam.54.285.

Searle, L. E. J., A. Best, A. Nunez, F. J. Salguero, L. Johnson, U. Weyer, A. H. Dugdale, W. A. Cooley, B. Carter, G. Jones, G. Tzortzis, M. J. Woodward, and R. M. La Ragione. 2009. A mixture containing galactooligosaccharide, produced by the enzymic activity of Bifidobacterium bifidum, reduces Salmonella enterica serovar Typhimurium infection in mice. J. Med. Microbiol. 58:37-48. https://doi.org/10.1099/jmm.0.004390-0.

Shahidi, F., J. K. V. Arachchi, and Y. J. Jeon. 1999. Food applications of chitin and chitosans. Trends Food Sci. Technol. 10:37-51. https://doi.org/10.1016/S0924-2244(99)00017-5.

Tanaka, Y., and T. Horiuchi. 1975. Purification and properties of B-Galactosidase from Aspergillus oryzae. J. Biochem. 77:241-247.

Tee, B. L., and G. Kaletunç. 2009. Immobilization of a thermostable $\alpha$-amylase by covalent binding to an alginate matrix increases high temperature usability. Biotechnol. Prog. 25:436-445. https://doi .org/10.1002/btpr.117

Torres, D. P. M., M. do P. F. Gonçalves, J. A. Teixeira, and L. R. Rodrigues. 2010. Galacto-Oligosaccharides: Production, properties, applications, and significance as prebiotics. Compr. Rev. Food Sci. Food Saf. 9:438-454. https://doi.org/10.1111/j.1541-4337.2010 $.00119 . x$.

Tzortzis, G., A. K. Goulas, J. M. Gee, and G. R. Gibson. 2005. A novel galactooligosaccharide mixture increases the bifidobacterial population numbers in a continuous in vitro fermentation system and in the proximal colonic contents of pigs in vivo. J. Nutr. 135:1726-1731.

Veereman-Wauters, G., S. Staelens, H. Van de Broek, K. Plaskie, F. Wesling, L. C. Roger, A. L. McCartney, and P. Assam. 2011. Physiological and bifidogenic effects of prebiotic supplements in infant formulae. J. Pediatr. Gastroenterol. Nutr. 52:763-771. https://doi .org/10.1097/MPG.0b013e3182139f39.

Wilchek, M., and T. Miron. 2003. Oriented versus random protein immobilization. J. Biochem. Biophys. Methods 55:67-70. https://doi .org/10.1016/S0165-022X(02)00178-1.

Yin, H., T. Pijning, X. Meng, L. Dijkhuizen, and S. S. Van Leeuwen. 2017. Engineering of the Bacillus circulans $\beta$-galactosidase product specificity. Biochemistry 56:704-711. https://doi.org/10.1021/acs .biochem.7b00032.

Yu, L., and D. J. O'Sullivan. 2014. Production of galactooligosaccharides using a hyperthermophilic beta-galactosidase in permeabilized whole cells of Lactococcus lactis. J. Dairy Sci. 97:694-703. https://doi.org/10.3168/jds.2013-7492.

Zheng, P., H. Yu, Z. Sun, Y. Ni, W. Zhang, Y. Fan, and Y. Xu. 2006. Production of galacto-oligosaccharides by immobilized recombinant beta-galactosidase from Aspergillus candidus. Biotechnol. J. 1:1464-1470. https://doi.org/10.1002/biot.200600100.

Zhou, Q. Z. K., and X. D. Chen. 2001. Effects of temperature and $\mathrm{pH}$ on the catalytic activity of the immobilized $\beta$-galactosidase from Kluyveromyces lactis. Biochem. Eng. J. 9:33-40. https://doi.org/ 10.1016/S1369-703X(01)00118-8. 